\title{
Influence of the Environmental Factors on the Coastal Zones Formation in the Siberian Urban Territories
}

\author{
Eugenia Ketova $^{1, *}$ and Nadezhda Burilo $^{1}$ \\ ${ }^{1}$ Novosibirsk State University of Architecture and Civil Engineering (SIBSTRIN), Leningradskaya \\ str., 113, Novosibirsk, 630089, Russia
}

\begin{abstract}
The coastal zones of Siberian large cities are characterized by high demand at various historical stages. Coastal territories are considered as potential reserves of the urban environment, their functions have great dynamics and high natural potential. The objective of the research is identifying the influence of environmental factors on the zones' landscape and town planning reorganization in the structure of the Siberian large cities' coastal territories. Research methods are an integrated approach which involves considering the research object as an element of a single town-planning structure, excluding the possibility of making limited and incomplete decisions. The study results are to build a green river facade as proposing solutions to environmental problems of "buffr zones". Significance of the study is to preserve the environmental balance of the large Siberian Rivers' territories. This comprehensive approach involves consideration of the research object as an element of a single town-planning structure. First of all it requires the identification of optimal territories for placing point objects in a complex terrain territory and choosing the most cost-effective and efficient reconstruction and revitalization methods, within the development of methods for their application in local conditions.
\end{abstract}

\section{Introduction}

Non-observance of environmental balance and industrial production increasing coursed negative results of urban development in large Siberian cities. The most difficulty was the disproportionate formation of coastal areas, as a result of the riverside areas position in large Siberian cities, characterized by their inefficient use and a significant degree of coastal reliefs' fragmentation.

The article deals with "coastal zone" concept, but it needs to specify that the definitions of the coastal zone concept still do not exist both at the legislative level and the development level of the Russian Federation doctrines. Relevant is only a reference to the Law on the State Land Cadastre, which defines the territorial zone concept.

\footnotetext{
* Corresponding author: michmacha@mail.ru
} 
Gogoberidze G.G. provides a review and analysis of the existing conceptual apparatus for the coastal zone and its components from the point of management and economic development view, relying on Russian legislation in this area and foreign terminological analogues in the article "Coastal zone".

The question of the coastal recreational zones planning is widely considered in Zadvoryanskaya T.I. "Landscaping and Town Planning Organization of Recreational Zones in the Structure of Large Cities Coastal Territories" work. The principles and methods of landscape-urban reconstruction are considered, a typology of public recreational spaces in the city coastal zone is developed. Scientifically grounded principles definition of largest cities industrial territories' reconstruction is considered in Frolov S.S. "Town-planning reconstruction of cities' coastal industrial territories" dissertation, he also developed a methodology for quantitative assessment of industrial buildings state, so the mode of a particular enterprise reconstruction is determined.

\section{Materials and Methods}

Coastal areas of Siberian large cities have a significant recreational potential and can be used for various entertainment types with the help of some clean-up activities. In order to identify the planning structure features and study the influence of environmental factors on the territories development, of the Western Siberian cities (Novosibirsk, Omsk and Tomsk) were chosen.

The cities' origin location was chosen in a natural way, so Tomsk terrain later was formed on a hill, the green massifs were as a natural barrier, and the Tom River served as an important defensive boundary. Omsk was founded as a fortress, defending the southern limits of the State boards. Waterways played a great historical role in the emergence and cities formation on the vast Siberian territory. The Novosibirsk region territory played the buffer zone role because of its location on the two natural zones border. It is historical and cultural regions (the Siberian Taiga and the Eurasian steppe), for millennia. The buffer zone simplifies protection of the rivers' ecological integrity, improves connections between wildlife habitats and allows rivers to function more naturally. It should be noted that the buffer zones creation reduces the impermeability and filters deposits (fertilizers and pesticides). They act as a filter and reduce the cost of water treatment systems, preventing polluters from entering them into drinking water sources. By the force of the river's buffer open areas protection, flood control can be achieved in an economically efficient manner. Buffer zones also play an important role in reducing of erosion risk and stabilize river banks with vegetation. A well-developed buffer zone helps in protecting water quality and wildlife habitat from industry. The buffer zones also provide shadow areas that reduce water temperature. The city territory is used in such way that production and communal facilities are adjacent to residential areas, which complicates the planning development of residential and recreational areas of the Ob River embankment. The peculiarity of the urban development situation is relatively few undeveloped sections of the territory within the city boundaries that can be used to form residential and public complexes. Otherwise, since the free territories' reserves for the complex construction are coming to their exhaustion, Novosibirsk has quickly developed inconvenient territories, such as coastal territories. Also there are low-rise buildings areas and industrial zones for reconstruction, and urban areas for expansion planning.

The results of the studies conducted within the framework of the Tomsk General Plan development show that there are $3.9 \mathrm{~m} 2$ of green space per inhabitant, comparing this indicator with the set of rules, it shows that the indicator is many times lower than the established rate (Table 1). In accordance with the city project, it is planned to build three bridges over the Tom River, as well as transport interchanges to the river through the 
district territory. In accordance with the general plan, Tomsk left bank has a recreational function. Such negative processes as river erosion, suffosion processes, waterlogging, flat flushing, ice, technogenic underflooding by groundwater, frosts punching on the Tomsk territory are observed [1].

Table 1. Maps-schemes of functional zones in Novosibirsk, Omsk, Tomsk



\begin{tabular}{|l|l|}
\hline Legend to Table 1 \\
\hline \\
\hline
\end{tabular} \mid \begin{tabular}{ll}
\hline \\
\hline
\end{tabular}

The climatic and landscape conditions of Tomsk left bank are favorable used for recreational purposes for a year-round. Omsk occupies a river valley: the floodplain, the first and second above-floodplain terraces and the indigenous shore. The first supralugal terrace on the right bank of the Irtysh slopes gently and carries a large part of the city. To the east and northeast the heights increase, here the second terrace is above the floodplain and the beginning of the watershed zone is divided into two parts by the Omi valley [2]. The terrain is flat; the monotonous relief is slightly disturbed by depressions of small flat valleys, river valleys, ancient drainage gullies and manes. The lower point is located in the floodplain; the upper one is on the watershed plateau. A distinctive feature of the territories is the shallow watercourses presence. Most of them go through ravines to the river valleys. Five bridges were built in the city. [3]. A significant part of industrial and residential buildings is on the right bank of the Irtysh. Recently, most of the urban housing construction is carried out on the left bank. The right bank construction is limited by the fact that it is situated just near the petrochemical enterprises in the north and the railway network and the machine building enterprise in the south. The density of Omsk population is 4,5 thousand people / $\mathrm{km} 2$. 


\section{Results}

After analyzing the Tomsk functional zones in (Table 2), it should be noted that the development of industrial, residential and recreational areas has almost completely reduced green spaces and transport infrastructure zones. Such division of territories is unacceptable and will inevitably lead to the territory ecological collapse, almost irreversible natural and anthropogenic phenomenon, which excludes the possibility of a man existence in the environment. The current and environmentally balanced development of Tomsk left bank can become one of the main innovative projects of the city, with a focus on current methods of organizing the natural spatial environment and created landscapes, the introduction of new developments, affecting transport and engineering systems of organization. The distribution of the territories adjacent to the water body in Omsk (Table 2) was as follows: the residential area is $11.1 \%$ of the territory, the industrial zone is $10.5 \%$, the zone of green spaces is $11.1 \%$, the recreational zone is $7.2 \%$, and the area of transport infrastructure is 4.7\%. Wastes and undeveloped territories make up $43.2 \%$.

Such development is characterized by large undeveloped intervals between the existing and new buildings. Large city construction changes the ecological and natural environment, as well as irreversibly affects the relief, soils, hydrological network and even the climate. But necessary human resources, such as clean air and water, are becoming increasingly inaccessible. Analyzing the functional zones of the Novosibirsk coastal areas (Table 2), it is revealed that the residential sector occupies $70 \%$ and it is mainly represented by low-rise private buildings. The industrial zones are located chaotically in close proximity to the residential zone, while the recreational area is practically in the city general territory; recreational areas occupy only $20 \%$. It should be noted that in comparison with Tomsk and Omsk, industrial and residential areas are distributed almost throughout the coastal zone.

Table 2. Functional zoning of coastal areas

\begin{tabular}{|c|c|c|c|}
\hline City & $\begin{array}{c}\square \\
\text { Residential area } \\
\text { development, \% }\end{array}$ & $\begin{array}{c}\square \text { Recreation } \\
\text { al Area, \% }\end{array}$ & $\begin{array}{c}\square \\
\text { Industrial } \\
\text { Zone, \% }\end{array}$ \\
\hline Novosibirsk & & $10,3 \%$ & $18 \%$ \\
\hline
\end{tabular}




\begin{tabular}{|l|l|l|l|}
\hline & $11,1 \%$ & $7,2 \%$ & $10,5 \%$ \\
\hline
\end{tabular}

\section{Discussion}

Planned cleaning of the reservoirs and their ecological status maintenance, as well as improvement of the rivers areas, can ensure their long-term and sustainable usage, which in general will have a fruitful impact on the environment.

Ecological and urban factors:

- a factor of environment ecological state (includes: atmospheric air, soil, underground and surface water, sanitary and epidemiological conditions, etc.), as well as criteria for the territory contamination;

- existing factor level of socio-industrial load (concentration of fixed productive assets working per unit of territory, population density per unit of territory, etc.);

- natural-hypergene stability of the environment (disturbance level of the territory and provision of engineering and material resources).

On this basis, problem areas for development can be identified, a strategy for townplanning measures to achieve normative and favorable living conditions of the population, as well as the corresponding stages of territory environmental and town-planning organization.

\section{Conclusion}

The part of architectural development, which forms a characteristic image (panorama of the city, river facade) should be supported by the choice of certain methods and coastal landscape organization means. They are playing an important part in ensuring accessibility to water recourses and the possibility of reviewing the city semantic dominants. In the process of embankments forming, it is necessary to take into account their location in the city planning structure, "boundary spaces" influence, which is the natural dominant (river, bay, and pond) in embankments' sections, industrial areas, office and residential buildings, transport infrastructure [4]. 
Nowadays, the quality of large Siberian cities' areas organization does not quite meet the main requirements: ecological safety, comfort, aesthetics, and the use of these territories at this stage are not as effective as natural resources. Water-green frame formation as a basic planning method will help to preserve and create more free territories in the structure of coastlines which perform recreational, recreational, and environmental functions.

\section{References}

1. M.A. Kashiro, Regularities of lakes' landscape structure in the floodplain type Tomsk territory, III International Scientific-Practical Conference, 26-29. (2014)

2. V.I. Kochedamov, Omsk. How the city was growing and being built, Omsk Book Publishing House, 112 (1960)

3. N.F. Khilko Dynamics of visually-aesthetic characteristics of Omsk image in the bridges and rivers landscapes comparison in the middle of $\mathrm{XX}$ - the beginning of the XXI century, Kemerovo, 195-207 (2016)

4. D.V. Litvinov, Gradoecological principles of coastal zones development (on the example of Volga region), Builds, St. Petersburg, 20 (2009)

5. A.I. Treyvish, The territory development and the territorial concentration of productive forces: the relationship and role in the process of intensification, IG AN SSSR, Moscow, 56 - 70 (1987) 